\title{
Dipeptidyl peptidase IV (DPP-IV) inhibition prevents fibrosis in adipose tissue of obese mice
}

\author{
Ana Patrícia Marques ${ }^{\mathrm{a}, \mathrm{b}}$, Janete Cunha-Santos ${ }^{\mathrm{a}, \mathrm{c}}$, Helena Leal ${ }^{\mathrm{a}}$, Lígia Sousa-Ferreira ${ }^{\mathrm{a}}$, \\ Luís Pereira de Almeidaa,c, Cláudia Cavadas ${ }^{\mathrm{a}, \mathrm{c}, 1}$, Joana Rosmaninho-Salgado ${ }^{\mathrm{a}, \mathrm{d}, *, 1}$ \\ ${ }^{\text {a }}$ CNC - Center for Neuroscience and Cell Biology, University of Coimbra, 3004-504 Coimbra, Portugal \\ ${ }^{\mathrm{b}}$ PDBEB - Doctoral Program in Experimental Biology and Biomedicine, Institute of Interdisciplinary Research (IIIUC), University of Coimbra, 3004-504 Coimbra, Portugal \\ c Faculty of Pharmacy, University of Coimbra, 3000-548 Coimbra, Portugal \\ ${ }^{\mathrm{d}}$ Department of Medical Genetics, Pediatric Unit, Coimbra, Hospital and University Center (CHUC), 3000-602 Coimbra, Portugal
}

\section{A R T I C L E I N F O}

\section{Keywords:}

Obesity

Fibrosis

Extracellular matrix

Dipeptidyl peptidase IV inhibitor

Vildagliptin

Neuropeptide Y

\begin{abstract}
A B S T R A C T
Background: During the development of obesity the expansion of white adipose tissue (WAT) leads to a dysregulation and an excessive remodeling of extracellular matrix (ECM), leading to fibrosis formation. These ECM changes have high impact on WAT physiology and may change obesity progression. Blocking WAT fibrosis may have beneficial effects on the efficacy of diet regimen or therapeutical approaches in obesity. Since dipeptidyl peptidase IV (DPP-IV) inhibitors prevent fibrosis in tissues, such as heart, liver and kidney, the objective of this study was to assess whether vildagliptin, a DPP-IV inhibitor, prevents fibrosis in WAT in a mouse model of obesity, and to investigate the mechanisms underlying this effect.

Methods: We evaluated the inhibitory effect of vildagliptin on fibrosis markers on WAT of high-fat diet (HFD)induced obese mice and on 3T3-L1 cell line of mouse adipocytes treated with a fibrosis inducer, transforming growth factor beta 1 (TGF $\beta 1)$.

Results: Vildagliptin prevents the increase of fibrosis markers in WAT of HFD-fed mice and reduces blood glucose, serum triglycerides, total cholesterol and leptin levels. In the in vitro study, the inhibition of DPP-IV with vildagliptin, neuropeptide Y (NPY) treatment and NPY $\mathrm{Y}_{1}$ receptor activation prevents ECM deposition and fibrosis markers increase induced by TGF $\beta 1$ treatment.

Conclusions: Vildagliptin prevents fibrosis formation in adipose tissue in obese mice, at least partially through NPY and NPY $\mathrm{Y}_{1}$ receptor activation.

General significance: This study highlights the importance of vildagliptin in the treatment of fibrosis that occur in obesity.
\end{abstract}

\section{Introduction}

Obesity is one of the most common health problems in developed countries and is characterized by an increase of white adipose tissue (WAT) expansion [1]. The WAT expansion ability is dependent on extracellular matrix (ECM) [2]. Moreover, ECM remodeling is a crucial event to the main WAT biological functions, such as adipogenesis and also for maintenance of tissue architecture [2]. However, in obesity it occurs excessive ECM deposition in adipose tissue, leading to fibrosis [3]. Fibrosis is characterized by deposition of ECM components, mainly collagens, which lead ultimately to organ dysfunction [4]. A major component of collagen is hydroxyproline which is often used as an indicator of collagen content [5]. Several profibrotic factors have been implicated in the development of fibrosis but the most important and potent profibrotic factor is transforming growth factor beta 1 (TGF $\beta 1$ ) [4]. TGF $\beta 1$ is an important player in fibrosis development and the decrease of this factor prevents fibrosis [4]. Furthermore, it was also described that subcutaneous WAT fibrosis decreases fat mass loss induced by surgery [6]. Moreover, it was demonstrated that collagen VInull $o b / o b$ mice show ameliorations in glucose and lipid metabolism [7]. Strategies that prevent or block WAT fibrosis have potential beneficial impact on the efficacy of diet regimen or therapeutical approaches in obesity.

Dipeptidyl peptidase IV (DPP-IV) is a multifunctional enzyme, which is expressed ubiquitously, including in visceral, epididymal and omental adipose tissue [8,9]. DPP-IV is a so-called "moonlighting

\footnotetext{
* Corresponding author at: CNC - Center for Neuroscience and Cell Biology, Rua Larga, University of Coimbra, 3004-517 Coimbra, Portugal.

E-mail address: jrosmaninho.salgado@chuc.min-saude.pt (J. Rosmaninho-Salgado).

1 These authors contributed equally to this work.
} 
protein" as it functions as a serine protease, a receptor, a costimulatory protein, and as an adhesion molecule for collagen and fibronectin [10]. DPP-IV cleaves peptides at the $\mathrm{N}$-terminal region after $\mathrm{X}$-proline or $\mathrm{X}$ alanine, such as glucagon-like peptide-1 (GLP-1), glucagon-like peptide2 (GLP-2) and gastric inhibitory polypeptide (GIP) and also neuropeptide Y (NPY) [11,12]. DPP-IV inhibitors mainly act to activate insulin secretion, inhibit glucagon secretion, improve $\beta$-cell mass, and to lower blood glucose [13]. For these reasons, several DPP-IV inhibitors are used as oral drugs for the treatment of type 2 diabetes [13].

Besides DPP-IV inhibitors action in lowering glucose, they have also been shown to have a protective role in other non-adipose tissues $[14,15]$. DPP-IV inhibitors were demonstrated to have a protective effect in preventing fibrosis in several organs, such as heart, liver and kidney, both in vitro and in vivo [16-18].

NPY was shown to be a DPP-IV substrate with an important role in adipose tissue physiology. NPY was observed to induce adipocyte differentiation and proliferation in 3T3-L1 cell line [19]. NPY also has an anti-lipolytic effect in adipocytes through NPY $\mathrm{Y}_{1}$ receptor [8]. Moreover, NPY was shown to have impact in fibrosis formation in non-adipose tissues. NPY was described to reduce fibrosis in a swine model of chronic myocardial ischemia and hypercholesterolemia [20]. NPY overexpression reduces the cardiac fibrosis development in other rat model [21]. The antifibrotic effects of NPY seem to occur through NPY $\mathrm{Y}_{1}$ receptor. Another study observed that mice lacking NPY $\mathrm{Y}_{1}$ receptor have more myocardial fibrosis [22].

Although DPP-IV inhibition and NPY were shown to be important in fibrosis in other tissues, the role of DPP-IV inhibition and NPY is not known in the pathogenesis of adipose tissue fibrosis in obesity. The hypothesis of this study is that DPP-IV inhibitor can prevent adipose tissue fibrosis in obesity.

Thus, the aim of this study was to investigate the role of DPP-IV inhibition, by vildagliptin, in adipose tissue fibrosis in a mouse model of diet-induced obesity and using also a 3T3-L1 preadipocyte cell line.

\section{Materials and methods}

\subsection{In vivo experiments}

All experimental procedures were performed in accordance with the European Union Directive 86/609/EEC for the care and use of laboratory animals. In addition, animals were housed in a licensed animal facility (international Animal Welfare Assurance number $520.000 .000 .2006)$ and the CNC animal experimentation board approved the utilization of animals for this project. Moreover, people coordinating the animal studies have received appropriate education (FELASA course) as required by the Portuguese authorities.

\subsection{Animals}

Eight-week old adult male C57BL/6 mice were purchased from Charles River Laboratories and were housed under a $12 \mathrm{~h}$ light/dark cycle in a temperature/humidity controlled room with ad libitum access to water and food. Mice were randomly divided into four groups and treated for seven weeks: two groups were maintained in normal chow diet ( $8 \%$ fat), one group with and the other without vildagliptin treatment $(30 \mathrm{mg} / \mathrm{kg} /$ day in water). The animals of the other two groups were maintained in a high-fat diet (HFD; LabDiet - Western diet for rodents) with $40 \%$ fat, also one group with and the other without vildagliptin treatment $(30 \mathrm{mg} / \mathrm{kg} /$ day in water). The chow group was composed of 13 mice. The chow group with vildagliptin treatment had 10 mice. The HFD group had 14 mice. The HFD group with vildagliptin treatment was composed of 14 mice. Body weight and food consumption were measured twice a week for a total of 7 weeks.

\subsection{Intraperitoneal glucose tolerance test}

Intraperitoneal glucose tolerance test (ipGTT) was performed at the sixth week of HFD. The test was performed after an overnight fast $(12 \mathrm{~h})$. The next morning mice were weighted and glycemic levels were measured using the FreeStyle Precision Neo glucometer (Abbot) (Time 0 ). Glucose administration was performed via injection $(2.0 \mathrm{~g} / \mathrm{kg}$, using a $20 \%$ glucose solution in saline $0.9 \% \mathrm{NaCl}$ ) into the peritoneal cavity. Glycemic levels were measured at 15, 30, 60, 90 and $120 \mathrm{~min}$ after glucose administration.

\subsection{Tissue collection}

At week 7, mice were sacrificed with a lethal dose of halothane (2bromo-2-chloro-1, 1, 1-trifluoroethane) followed by decapitation. Liver and WAT (epididymal fat pad) were collected. The WAT was weighted and, afterwards, samples were collected, immediately frozen in dry ice and kept at $-80^{\circ} \mathrm{C}$. Blood was collected; the serum was separated by centrifugation $(2000 \times \mathrm{g}, 15 \mathrm{~min})$ and stored at $-20^{\circ} \mathrm{C}$.

\subsection{Serum triglycerides and cholesterol determination}

Serum triglyceride and cholesterol levels were quantified using the automatic biochemical analyzer Integra 800 (Roche).

\subsection{Serum leptin and insulin quantification}

Serum levels were measured for leptin and insulin with commercially available ELISA kits from EMD Millipore. All ELISA-based measurements were performed according to manufacturers' instructions.

\subsection{Tissue preparation for histological processing}

Mice were sacrificed with an overdose of avertin (2.5 times of $14 \mu \mathrm{L} / \mathrm{g}, 250 \mathrm{mg} / \mathrm{kg}$, intraperitoneally). Transcardial perfusion with phosphate solution and fixation with $4 \%$ paraformaldehyde were performed. The epididymal adipose tissue and liver were collected and postfixed in 4\% paraformaldehyde and cryoprotected by incubation in $25 \%$ sucrose/phosphate buffer. After that, dry tissues were embedded in paraffin, and subsequently cut into $3 \mu \mathrm{m}$-thick sections in a microtome.

\subsection{Hematoxylin and eosin staining}

For histological analysis of paraffin sections, epididymal adipose tissue and liver were stained with hematoxylin and eosin (HE). Slides were kept for $30 \mathrm{~min}$ at $68{ }^{\circ} \mathrm{C}$ to melt the paraffin. After 2 washes in xylene for 3 and $2 \mathrm{~min}$, slides were transferred to a glass coplin jar containing $100 \%$ ethanol for $4 \mathrm{~min}$ and $95 \%$ for $2 \mathrm{~min}$ and rinsed 2 times with distilled water for $30 \mathrm{~s}$. Slides were stained in hematoxylin Gill III for 5 min and bathed 2 times in distilled water for 2 and 1 min. After that, slides were stained with eosin for $1 \mathrm{~min}$ and dehydrated with 2 fast rinses in water, $95 \%$ and $100 \%$ of ethanol in water for $1 \mathrm{~min}$ and 2 times with xylene for 2 min. Glass slides were then mounted.

\subsection{Adipocyte diameter quantification}

Epididymal adipose tissue sections were stained with HE. The tissue was visualized using a fluorescence microscope (Axioskop 2 Plus, Zeiss, Jena, Germany) and the images were acquired with Axiovision software (release 4.7). Axiovision software was used to measure adipocyte diameter, which is represented as the average adipocyte diameter (in $\mu \mathrm{m}$ ). Adipocyte diameter was measured from four groups of mice $(>100$ cells/group). 


\subsection{Picrosirius red staining}

For collagen analysis, epididymal adipose tissue was stained with Picrosirius red [23]. Slides were kept for $30 \mathrm{~min}$ at $68^{\circ} \mathrm{C}$ to melt the paraffin. Slides were washed 2 times in xylene for $10 \mathrm{~min}$, and then transferred to $100 \%, 95 \%, 85 \%, 75 \%, 60 \%$ and $50 \%$, for 5 min each and rinsed 2 times with distilled water for $30 \mathrm{~s}$. Nuclei were stained with Weigert's hematoxylin for 5 min and washed 2 times with distilled water for $5 \mathrm{~min}$. After that, slides were stained with a solution of Picrosirius Red $(0.1 \%$ Picrosirius Red in a saturated solution of Picric Acid) for $1 \mathrm{~h}$ and rinsed twice with acidified water. Slides were then dehydrated with $50 \%, 60 \%, 75 \%, 85 \%, 95 \%$ and $100 \%$ of ethanol in water for $5 \mathrm{~min}$ each and 2 washes with xylene for $10 \mathrm{~min}$. Glass slides were then mounted.

The cells were visualized using the microscope Axio Imager $Z 2$ and the images were acquired with Carl Zeiss Zen software. Collagen was quantified using FIJI (Fiji is Just ImageJ) software (National Institutes of Health). Five images were analyzed for each condition, and data are representative of at least three independent experiments.

\subsection{Hydroxyproline quantification}

Hydroxyproline measurement was done using a modified protocol that was described elsewhere [5]. Briefly, $20 \mathrm{mg}$ of frozen fat or 3T3-L1 cells were heated in $6 \mathrm{~N} \mathrm{HCl}$ at $110^{\circ} \mathrm{C}$ overnight in sealed tubes. The samples were then heated at $110^{\circ} \mathrm{C}$ until dried. Each sample was incubated with chloramine-T (Sigma Aldrich) at room temperature for exactly $20 \mathrm{~min}$ and then with $p$-dimethylaminobenzaldehyde (Fisher Scientific) at $60{ }^{\circ} \mathrm{C}$ for $15 \mathrm{~min}$. The absorbance was read at $540 \mathrm{~nm}$ and the concentration was determined by the standard curve created with cis-4-hydroxy-L-proline (Sigma-Aldrich).

\subsection{Viral vectors production}

Lentiviral vectors encoding for a negative short hairpin RNA (LVPGK-EGFP-H1-shRNA control) and a short hairpin RNA targeting DPPIV (LV-PGK-EGFP-H1-shRNA DPP-IV) were produced in HEK293T cell line with a four-plasmid system, as previously described [24]. Lentiviral particles were suspended in sterile 1\% BSA in PBS. Concentrated viral stocks were stored at $-80^{\circ} \mathrm{C}$, until use.

\subsection{Engineering of short hairpin RNA}

A negative short hairpin RNA (shRNA) (control) and shRNA targeting mouse DPP-IV were created. For each one, a pair of oligomers was designed. The sequences of each pair of oligomers used were: shRNA control (top 5' GATCCCCCAACAAGATAAGAGCACCAATTCAA GAGATTGGTGCTCTTCATCTTGTTG3TTTTTA 3'/bot 5' AGCTTAAAAA CAACAAGATGAAGAGCACCAATCTCTTGAATT GGTGCTCTTCATCTTG TTGGGG 3') and shRNA DPP-IV (top 5' GATCCCCATAAGATCATCAG CGACAAAGTTCAAGAGACTTTGTCGCTGATGATCTTATTTTTTA $3^{\prime}$ /bot 5' AGCTTAAAAAATAAGATCATCAGCGACAAAGTCTCTTGAAC TTTGT CGCTGATGATCTTATGGG 3'). Each pair of oligomers were annealed and inserted in linearized (with BglII and HindIII restriction enzymes) pENTR/pSUPER ${ }^{+}$(AddGene 575-1). The H1-shRNA cassette was then transferred, with LR clonase recombination system, into SIN-cPPT-PGKEGFP-WHV-LTR gateway vector.

\subsection{Cell culture of 3T3-L1 preadipocyte cell line}

Cell cultures were performed as described previously [25]. For the experiences with genetic DPP-IV silencing, cells were plated in a sixwell plate and $24 \mathrm{~h}$ later were infected with lentiviral vectors encoding for negative shRNA control (LV-PGK-EGFP-H1-shcontrol) or for shRNA targeting DPP-IV (LV-PGK-EGFP-H1-shDPP-IV) with infectious media. At 2 weeks post-infection, cells were plated and induced to differentiate as we previously described [25].

\subsection{Preadipocyte differentiation}

Preadipocyte 3T3-L1 differentiation was performed as we previously described [25]. To evaluate the effect of a fibrotic inducer, 3T3L1 preadipocytes were treated during the differentiation of the cells with TGF $\beta 1$ ( $2.5 \mu \mathrm{g} / \mathrm{mL}$; Peprotech), vildagliptin ( $2 \mathrm{nM})$, NPY (100 nM; Phoenix Pharmaceuticals), NPY $\mathrm{Y}_{1}$ receptor agonist $\left(\mathrm{Leu}^{31} \mathrm{Pro}^{34} \mathrm{NPY}\right.$, $100 \mathrm{nM}$; Bachem), NPY $\mathrm{Y}_{2}$ receptor agonist $\left(\mathrm{NPY}_{13-36}, 100 \mathrm{nM}\right.$; Bachem) or the NPY $\mathrm{Y}_{5}$ receptor agonist $\left(\mathrm{NPY}_{19-23}\left(\mathrm{Gly}^{1}, \mathrm{Ser}^{3}, \mathrm{Gln}^{4}, \mathrm{Thr}^{6}\right.\right.$, $\left.\mathrm{Ala}^{31}, \mathrm{Aib}^{32}, \mathrm{Gln}^{34}\right) \mathrm{PP}, 100 \mathrm{nM}$; Bachem) and NPY neutralizing antibody at the C-terminal (NPY05; $6 \mu \mathrm{g} / \mathrm{mL}$ ) [26].

\subsection{Immunofluorescence}

Following fixation and permeabilization, nonspecific binding was blocked with 3\% BSA. Cells were incubated with the following primary antibodies, anti- $\alpha$ SMA (1:500), anti-fibronectin (1:1000) or anti-collagen VI $(1: 500)$ overnight, at $4{ }^{\circ} \mathrm{C}$. After rinsing with PBS, the cells were incubated with the appropriate secondary antibodies for $1 \mathrm{~h}$ (1:200, anti-rabbit or anti-mouse IgGs conjugated with Alexa Fluor 488 or Alexa Fluor 594), at room temperature. All antibodies were prepared in blocking solution (PBS containing 3\% of BSA). Nuclei were labeled with Hoechst $33342(1 \mu \mathrm{g} / \mathrm{mL})$ for $3 \mathrm{~min}$, after incubation with the secondary antibodies. Coverslips were mounted on glass slides, the cells were visualized using a fluorescence microscope (Carl Zeiss Axio Observer Z1) and the images were acquired with Carl Zeiss Zen software. Fluorescence was quantified using FIJI (Fiji is Just ImageJ) software (National Institutes of Health) and averaged per image. Five images were analyzed for each condition, and data are representative of at least three independent experiments.

\subsection{Protein quantification and sample preparation}

Cells were rinsed twice with ice-cold PBS and then lysed with RIPA buffer (50 mM Tris-HCl, pH 7.4; $150 \mathrm{mM} \mathrm{NaCl} ; 5$ mM EDTA; $1 \%$ Triton X-100; 0.5\% deoxycholate; 0.1\% SDS; $200 \mu \mathrm{M}$ PMSF; $1 \mathrm{mM}$ DTT, $1 \mathrm{mM}$ Na3VO4; $10 \mathrm{mM} \mathrm{NaF),} \mathrm{supplemented} \mathrm{with} \mathrm{mini} \mathrm{protease} \mathrm{inhibitor}$ cocktail tablet (Roche, Germany). Lysates were centrifuged at $12000 \times g$, for $15 \mathrm{~min}$ at $4{ }^{\circ} \mathrm{C}$. Protein concentration was determined by the Bradford assay (Biorad) and denatured with SDS buffer (0.5 M Tris, $30 \%$ glycerol, $10 \%$ SDS, 0.6 M DTT, $0.012 \%$ bromophenol blue). After heating for $5 \mathrm{~min}$ at $95^{\circ} \mathrm{C}$, the samples were frozen at $-20^{\circ} \mathrm{C}$ until use.

Adipose tissue was sonicated at $4{ }^{\circ} \mathrm{C}$ in RIPA buffer $(50 \mathrm{mM}$ Tris$\mathrm{HCl}, \mathrm{pH} 7.4 ; 150 \mathrm{mM} \mathrm{NaCl} ; 5 \mathrm{mM}$ EDTA; $1 \%$ Triton X-100; $0.5 \%$ deoxycholate; $0.1 \%$ SDS; $200 \mu \mathrm{M}$ PMSF; $1 \mathrm{mM}$ DTT, $1 \mathrm{mM}$ Na3VO4; $10 \mathrm{mM} \mathrm{NaF}$ ), supplemented with mini protease inhibitor cocktail tablet (Roche, Germany). Lysates were centrifuged at $1000 \times g$, for $5 \mathrm{~min}$ at $10{ }^{\circ} \mathrm{C}$ and the supernatant collected and centrifuged at $3300 \times g$, for $5 \mathrm{~min}$ at $4{ }^{\circ} \mathrm{C}$. Protein concentration was determined by the Bradford assay (Biorad) and denatured with SDS buffer (0.5 M Tris, 30\% glycerol, $10 \%$ SDS, $0.6 \mathrm{M}$ DTT, $0.012 \%$ bromophenol blue). After heating for $5 \mathrm{~min}$ at $95{ }^{\circ} \mathrm{C}$, the samples were frozen at $-20{ }^{\circ} \mathrm{C}$ until use.

\subsection{Western blotting}

Samples were separated in a $4-10 \%$ SDS-PAGE followed by electrophoretic transfer onto PVDF membranes. The membranes were blocked with $5 \%$ non-fat milk in TBS-T (137 mM NaCl, $20 \mathrm{mM}$ Tris, $0.1 \%$ Tween 20, pH 7.6) and incubated overnight at $4{ }^{\circ} \mathrm{C}$ with antiaSMA (1:500), anti-fibronectin (1:1000), anti- $\beta$-actin (1:10000) or anti$\beta$-tubulin (1:10000) antibodies diluted in blocking solution. After three washes with TBS-T, the membranes were incubated for $1 \mathrm{~h}$, at room temperature, with an alkaline phosphatase-linked secondary antibody, specific to rabbit or mouse immunoglobulin G (1:20000, Amersham 
Biosciences, GE Healthcare, UK). Immunoreactive bands were visualized using ECF substrate in the Versa-Doc 3000 imaging system (BioRad, USA). Densitometry of the bands was quantified using Quantity One Software (Bio-Rad, USA).

\subsection{Statistical analysis}

Results are expressed as mean \pm SEM. Data were analyzed using one-way ANOVA or two-way ANOVA, as indicated in figure legends. A value of $\mathrm{p}<0.05$ was considered significant. Prism 6.0 (GraphPad Software) was used for all statistical analysis.

\section{Results}

\subsection{Vildagliptin has no effect on body weight of HFD mice, but reduces serum triglycerides and total cholesterol}

Eight-week-old C57BL/ 6 mice were given a standard chow diet or a HFD and were treated with vildagliptin for 7 weeks. The vildagliptin treatment of mice under chow diet, for 7 weeks, did not change body weight gain, food intake, serum triglycerides, total cholesterol, insulin and leptin, when compared to non-treated mice (Table 1).

As expected, HFD-fed mice have a significantly increase in percentage of body weight gain in comparison with chow diet-fed mice (Table 1 and Fig. 1D). The HFD has higher energy content than the chow diet (4.49 kcal/g vs $2.268 \mathrm{kcal} / \mathrm{g}$ ); the increased body weight of mice fed HFD is associated to an increased energy intake in comparison to mice fed a chow diet (Table 1).

Despite the maintenance of body weight increase, vildagliptintreated mice fed with a HFD have reduced serum triglycerides and total cholesterol levels, when compared to non-treated mice (Table 1).

\subsection{Vildagliptin decreases blood glucose and improves glucose tolerance but does not alter epididymal adipose tissue weight nor adipocyte diameter}

Vildagliptin-treated mice fed a chow diet compared to non-treated mice show no difference in fasting blood glucose (Fig. 1A) neither on glucose kinetics measured by intraperitoneal glucose tolerance test (ipGTT) (Fig. 1B-C; area under the curve (AUC)). Fasting glucose levels in HFD mice are increased, when compared to mice in chow diet and vildagliptin prevents this increase (Fig. 1A). When challenged with an ipGTT, HFD mice treated with vildagliptin have improved glucose clearance for the duration of the challenge, when compared to nontreated HFD mice (Fig. 1B-C). Serum insulin levels significantly increase in HFD mice in comparison to chow diet, but no significant differences were observed in vildagliptin-treated mice (Table 1). Serum leptin levels are also significantly increased in HFD mice that is prevented with vildagliptin treatment (Table 1 ).

As expected, epididymal adipose tissue weight is significantly higher in the HFD group compared to chow group. This adipose tissue weight increase is not altered with vildagliptin treatment (Fig. 1E). In agreement, adipocyte diameter is increased in WAT of HFD group, when compared to chow diet mice, and vildagliptin does not change this parameter (Fig. 1F-G).

\subsection{Vildagliptin prevents fibrosis markers increase in adipose tissue of HFD} mice

Increased collagen and matrix deposition are key features of fibrosis that occur in adipose tissue of obese mice [3]. The Picrosirius red staining is used for histological visualization of collagen I and III fibers and thereby used to assess fibrosis [23]. Moreover, hydroxyproline is a major component of collagen and the measurement of this amino acid can be used as an indicator of collagen content [5]. We observed by Picrosirius red staining and hydroxyproline content, that collagen is increased in WAT of mice fed a HFD when compared to chow-fed mice (Fig. 2A-C). Vildagliptin-treated HFD mice have lower levels of WAT total collagen, in comparison to non-treated mice (Fig. 2A-C). By western blotting assay we evaluated the levels of $\alpha$ smooth muscle actin ( $\alpha$ SMA) and fibronectin, two profibrotic proteins. WAT of HFD-fed mice showed significantly higher aSMA and fibronectin levels, compared to WAT of chow diet-fed mice (Fig. 2D-E). Vildagliptin treatment decreases the levels of aSMA and fibronectin in WAT of mice fed a HFD (Fig. 2D-E). These results suggest that vildagliptin decreases fibrosis formation in WAT of HFD-induced obese mice.

Obesity is often associated with ectopic lipid accumulation due to incapacity of adipose tissue to accumulate more lipids and thereby hepatic steatosis can occur. Analysis of livers from control mice on HFD reveals an increase in lipid content compared with mice fed regular chow diet (Fig. 2F). Moreover, livers from vildagliptin-treated mice on HFD show lower levels of lipid droplet accumulation when compared to livers from non-treated HFD-fed mice (Fig. 2F).

\subsection{Vildagliptin prevents collagen and matrix deposition markers in TGFß1- stimulated 3T3-L1 cell line}

In order to clarify the mechanism through which vildagliptin can prevent fibrosis in adipose tissue, we first evaluated whether vildagliptin was able to prevent collagen and matrix deposition in vitro. We used a preadipocyte cell line, 3T3-L1, and mimicked fibrosis by treating the cells with $2.5 \mathrm{ng} / \mathrm{mL}$ of TGF- $\beta 1$ [27]. After 7 days of treatment with this fibrosis inducer, we observed an increase in $\alpha$ SMA and fibronectin levels that is prevented with vildagliptin treatment (Fig. 3C and G). We also evaluated the levels of $\alpha$ SMA, fibronectin and collagen VI by immunofluorescence. TGF- $\beta 1$ increases the immunoreactivity of $\alpha \mathrm{SMA}$, fibronectin and collagen VI and vildagliptin is able to prevent this increase (Fig. 3A-B, E-F and I-J). Total collagen content was evaluated by determination of hydroxyproline content. We also observed a

Table 1

Parameters measured in mice fed a Chow or HFD with or without vildagliptin treatment for 7 weeks.

\begin{tabular}{|c|c|c|c|c|}
\hline & Chow & Chow $+\mathrm{V}$ & HFD & $\mathrm{HFD}+\mathrm{V}$ \\
\hline Body weight change (\%) & $18.9 \pm 1.7$ & $20.6 \pm 1.1$ & $34.0 \pm 2.6^{* * *}$ & $37.7 \pm 2.4^{* * * *}$ \\
\hline Food intake/mice/day (calories) & $9.1 \pm 0.2$ & $8.5 \pm 0.1$ & $17.7 \pm 0.02^{* * * *}$ & $16.6 \pm 0.3^{* * * * \#}$ \\
\hline Serum triglycerides $(\mathrm{mg} / \mathrm{dL})$ & $72.9 \pm 4.3$ & $86.1 \pm 8.9$ & $184.9 \pm 9.1^{* * *}$ & $141.2 \pm 10.5^{* * *, \# \#}$ \\
\hline Serum cholesterol (mg/dL) & $127.9 \pm 31.1$ & $138.6 \pm 38.9$ & $334.8 \pm 35.5^{* *}$ & $162.3 \pm 25.4^{\#}$ \\
\hline Serum insulin $(\mathrm{ng} / \mathrm{dL})$ & $0.47 \pm 0.15$ & $0.30 \pm 0.09$ & $2.26 \pm 0.84$ & $1.51 \pm 0.54$ \\
\hline Serum leptin (ng/dL) & $1.6 \pm 0.3$ & $2.7 \pm 0.8$ & $19.2 \pm 4.6^{* * * *}$ & $10.8 \pm 1.8^{* * * \#}$ \\
\hline
\end{tabular}

Mean \pm SEM, $\mathrm{n}=4-14$

$* \mathrm{p}<0.05$.

*** $\mathrm{p}<0.01$

${ }^{* * *} \mathrm{p}<0.001$ compared to chow group.

\# $\mathrm{p}<0.05$.

\#\# $\mathrm{p}<0.01$ compared to HFD group. One-way ANOVA was used as statistical test. 


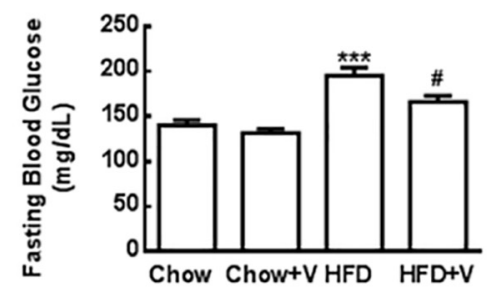

C

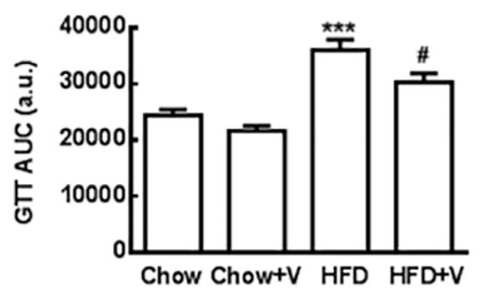

B

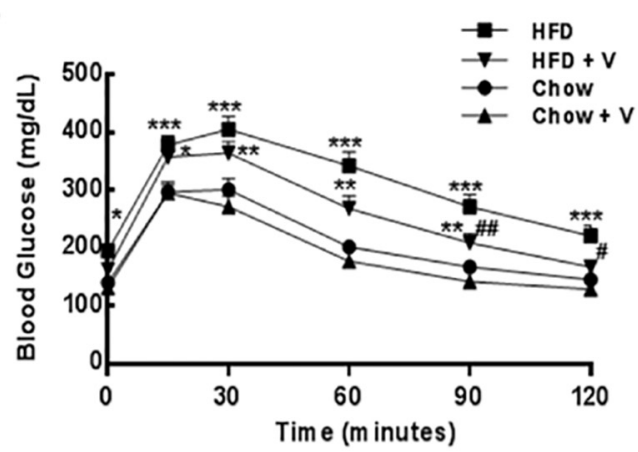

D

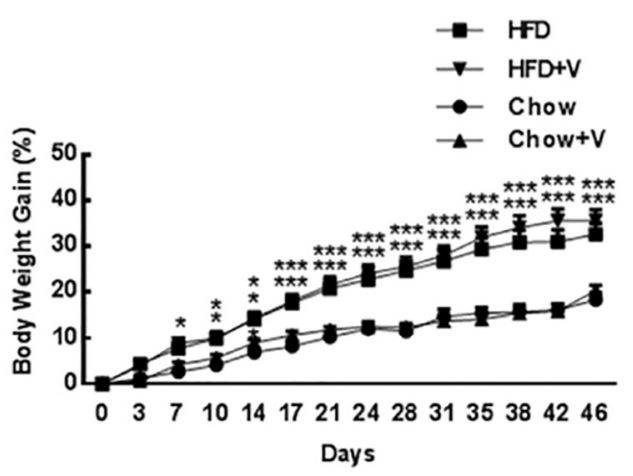

Fig. 1. Vildagliptin decreases blood glucose, improves glucose tolerance and has no effect on body weight gain, epididymal white adipose tissue and adipocyte diameter. (A) Fasting blood glucose, (B) blood glucose during intraperitoneal glucose tolerance test, two-way ANOVA was used as statistical test, (C) area under the curve (0-120 $\mathrm{min}$ ) of blood glucose of intraperitoneal glucose tolerance test in Chow and HFD group with and without vildagliptin treatment (V). $\mathrm{n}=9-13$ *p $<0.05 ; * * \mathrm{p}<0.01 ; * * * \mathrm{p}<0.001$ compared to Chow group. ${ }^{\#} \mathrm{p}<0.05 ;{ }^{\# \#} \mathrm{p}<0.01$ compared to HFD group. One-way ANOVA was used as statistical test; (D) Cumulative body weight gain presented as percentage of initial weight ( $n=10-14)$, two-way ANOVA was used as statistical test, (E) epididymal adipose tissue weight $(n=7-10)$, (F) representative image of hematoxylin and eosin staining in epididymal adipose tissue ( $n=3$; Scale bar: $50 \mu \mathrm{m})$, (G) adipocyte diameter $\quad(n=3) . \quad * \mathrm{p}<0.05 ; \quad * * \mathrm{p}<0.01$; $* * * \mathrm{p}<0.001$ compared to Chow group. One-way ANOVA was used as statistical test.
E

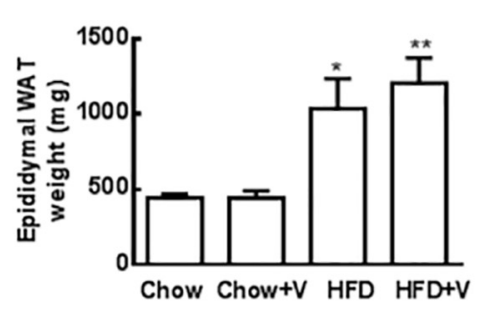

G

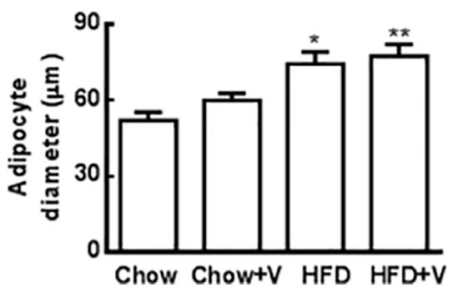

$\mathbf{F}$

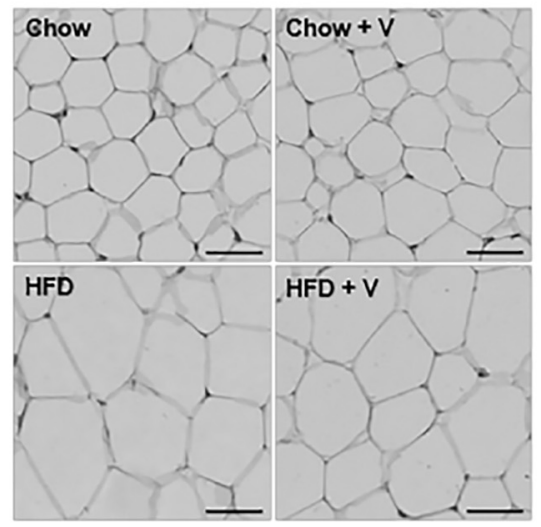

significant increase of total collagen content in cells treated with TGF$\beta 1$. Vildagliptin inhibits TGF- $\beta 1$-induced total collagen stimulation (Fig. 3K). To better understand the direct effect of DPP-IV inhibition, by vildagliptin, in ECM deposition and remodeling, we silenced DPP-IV using a shRNA targeting DPP-IV. Fibrosis was induced in 3T3-L1 cells with TGF $\beta 1$ and DPP-IV was genetically silenced. We evaluated, by western blotting, the protein levels of aSMA and fibronectin. As expected, we observed that TGF $\beta 1$ increases $\alpha$ SMA and fibronectin and that DPP-IV silencing significantly decreases both $\alpha$ SMA and fibronectin levels (Fig. 3D and H). We further evaluated total collagen content, and we observed that TGF $\beta 1$ increases total collagen and when DPP-IV is silenced the levels of total collagen decrease (Fig. 3L). In conclusion, our results suggest that inhibition of DPP-IV by vildagliptin and by genetic tools prevents collagen and matrix deposition in TGF $\beta 1$ treated 3T3-L1 cells.
3.5. Vildagliptin abrogates the TGFß1-induced alterations in ECM through $N P Y Y_{1}$ receptor activation

To further clarify the underlying mechanisms of DPP-IV inhibitor vildagliptin as an antifibrotic agent, we investigated the role of one DPP-IV substrate, the NPY, on ECM. This hypothesis was based on the fact that NPY is a substrate of DPP-IV, and it is implicated in the regulation of fibrosis in a swine model of chronic myocardial ischemia and hypercholesterolemia [20].

To study the effect of NPY on ECM, cells were treated with NPY $(100 \mathrm{nM})$ in the presence of TGF $\beta 1$. We observed, by western blotting, that NPY significantly decreases the levels of $\alpha$ SMA and fibronectin induced by TGF $\beta 1$, when compared to TGF $\beta 1$ alone (Fig. 4A-B). NPY also decreases total collagen content in TGF $\beta 1$-treated cells (Fig. 4C). Moreover, in order to study whether vildagliptin effect occurs through NPY receptor activation by released NPY, cells were treated with TGF $\beta 1$ and vildagliptin in the presence of a neutralizing NPY antibody, NPY05 
A

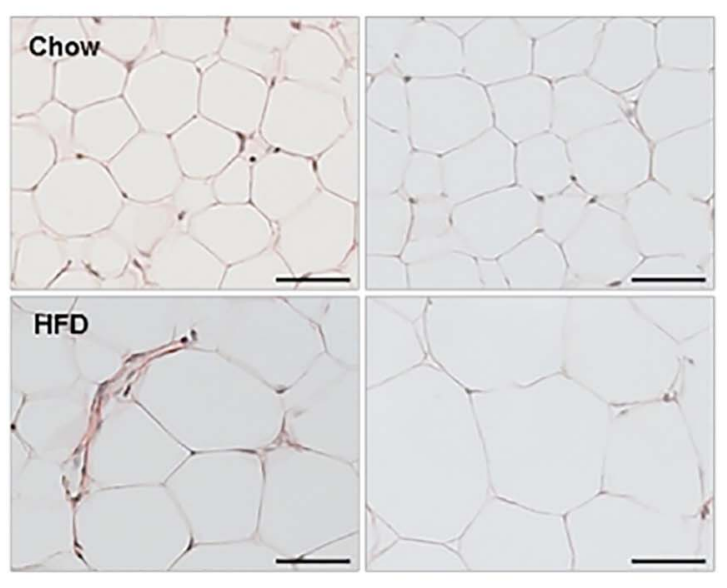

D

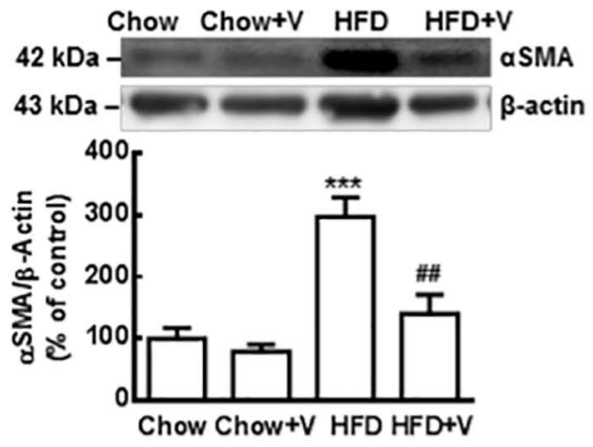

$\mathbf{F}$

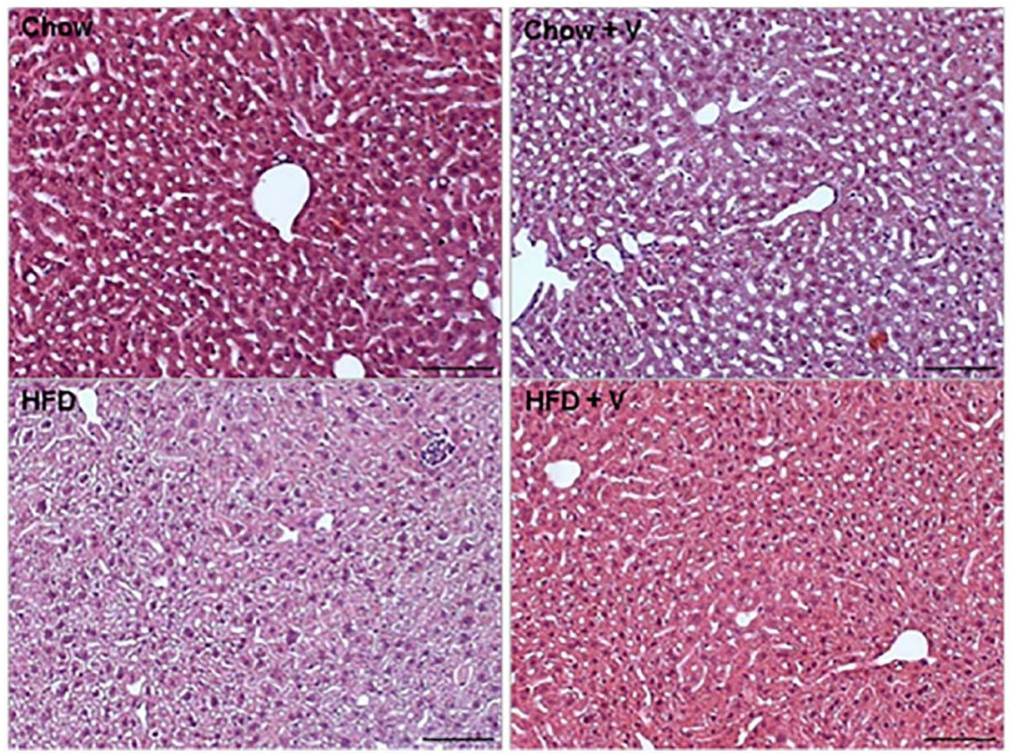

B

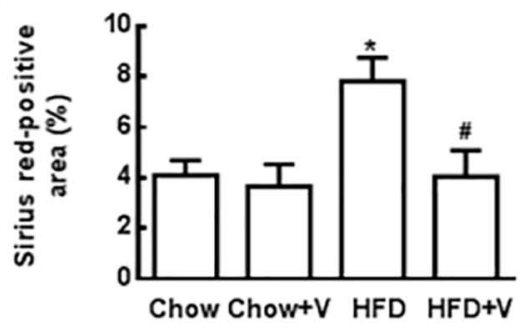

C

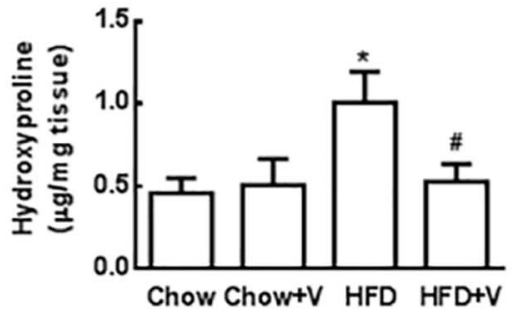

E

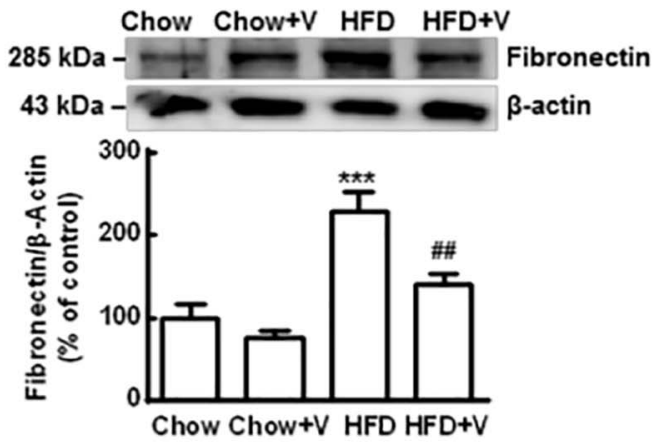

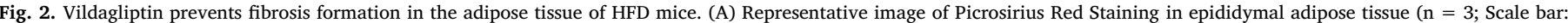

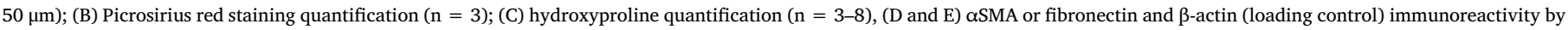

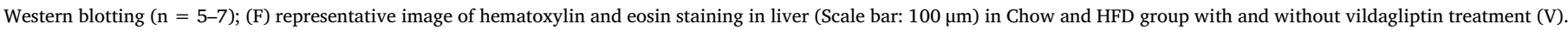
${ }^{*} \mathrm{p}<0.05 ;{ }^{* * *} \mathrm{p}<0.001$ compared to Chow group. \#p $<0.05 ; \#$ \# $<0.01$ compared to HFD group. One-way ANOVA was used as statistical test. 
A

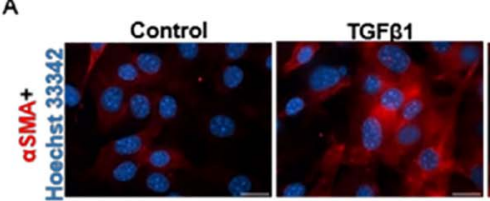

C
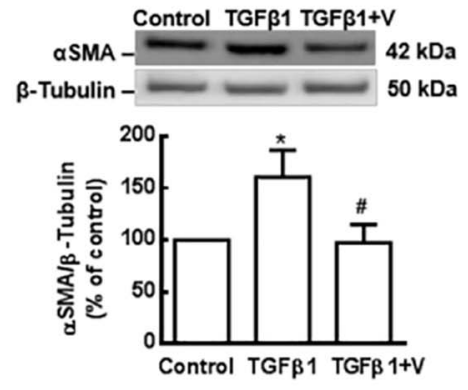

E

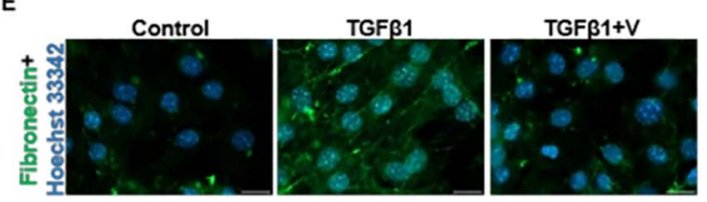

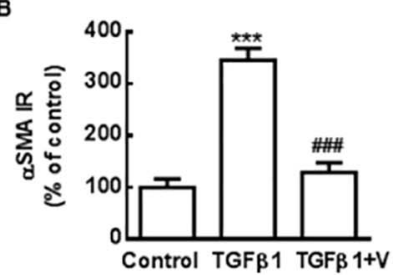

D

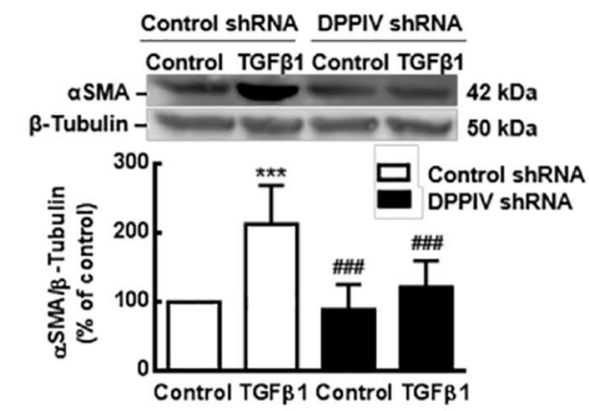

Fig. 3. Vildagliptin and DPP-IV silencing prevent fibrosis formation. 3T3-L1 preadipocytes were induced to differentiate and were treated with TGF $\beta 1(2.5 \mathrm{ng} / \mathrm{mL})$ in the presence or absence of vildagliptin $(\mathrm{V}, 2 \mathrm{nM})$ for seven days. (A, E, I) Representative images of immunofluorescence for $\alpha$ SMA (red), fibronectin (green) and collagen VI (green). Nuclei were stained with Hoechst 33342 (blue). Scale bar: $20 \mu \mathrm{m}$ (B, F, J) Quantification of $\alpha \mathrm{SMA}$, fibronectin and collagen VI immunofluorescence immunoreactivity. (C, G) aSMA or fibronectin and $\beta$-tubulin (loading control) immunoreactivity by Western blotting. (K) Hydroxyproline quantification. $\mathrm{n}=3-10 * \mathrm{p}<0.05$ *** $\mathrm{p}<0.001$ compared to control. ${ }^{\#} \mathrm{p}<0.05$; \#\#\# $\mathrm{p}<0.001$ compared to TGF $\beta 1$. One-way ANOVA was used as statistical test. 3T3-L1 preadipocytes were infected with lentivirus encoding a negative short hairpin RNA (control condition) or a short hairpin RNA targeting DPPIV. (D, H) aSMA or fibronectin and $\beta$-tubulin (loading control) immunoreactivity by Western blotting. (L) Hydroxyproline quantification. $\mathrm{n}=4-7 \quad * * \mathrm{p}<0.01$; $* * * \mathrm{p}<0.001$; compared to control of control shRNA. ${ }^{\#} \mathrm{p}<0.05$; ${ }^{\# \# \#} \mathrm{p}<0.001$; compared to TGF $\beta 1$-treated control shRNA. One-way ANOVA was used as statistical test.
G
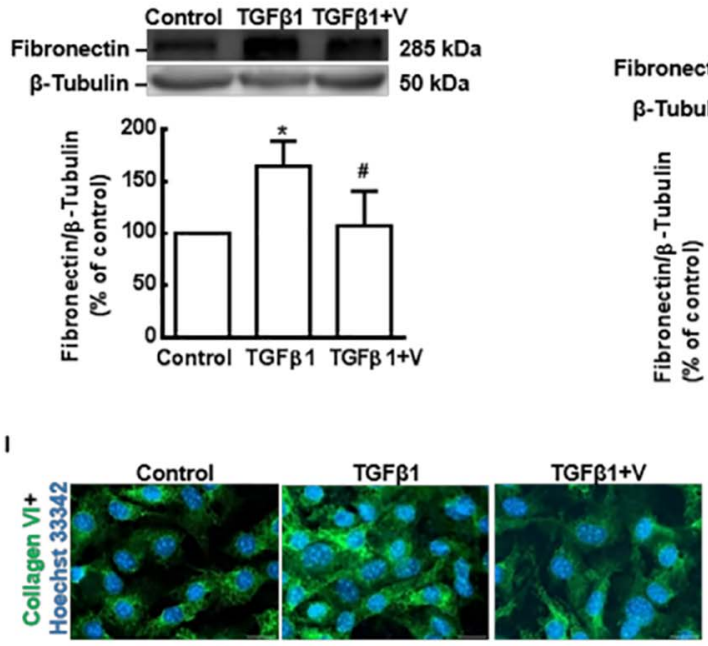

F

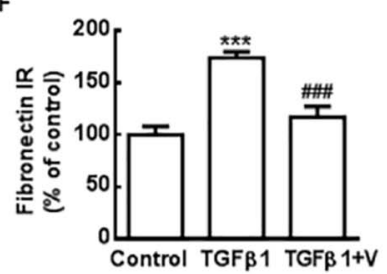

H
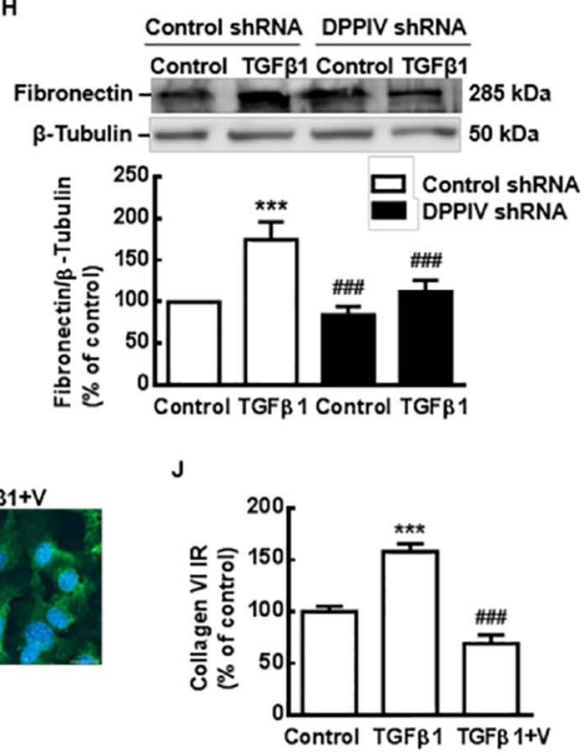

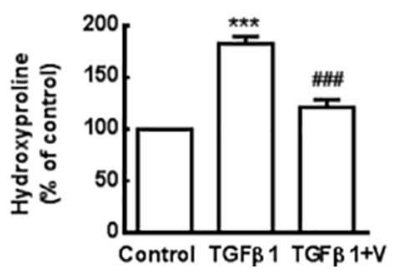

L

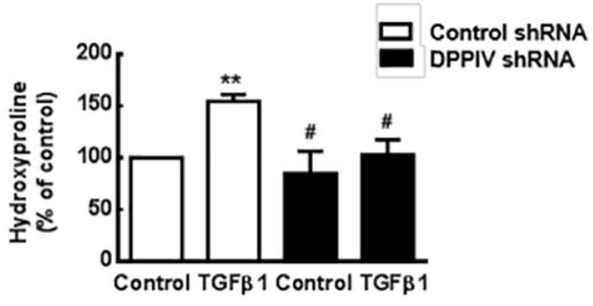


A

Control TGFß1 TGF $1+N P Y$
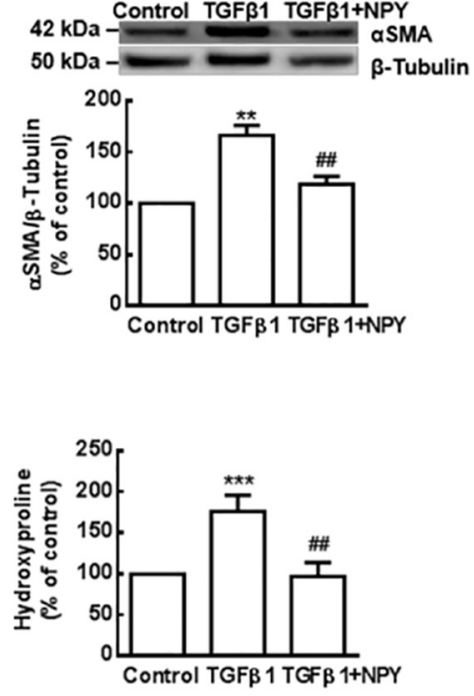

E

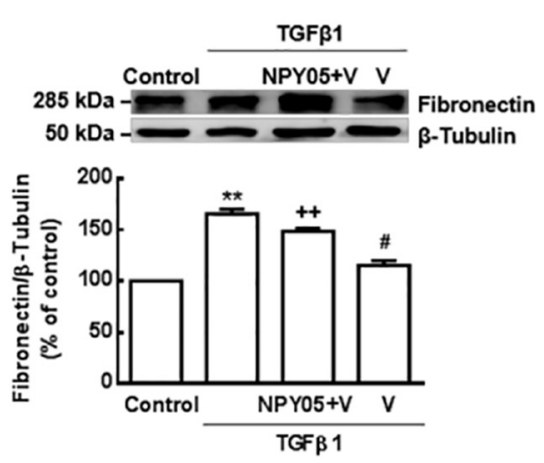

D

Control TGF 1 TGF $\beta 1+N P Y$
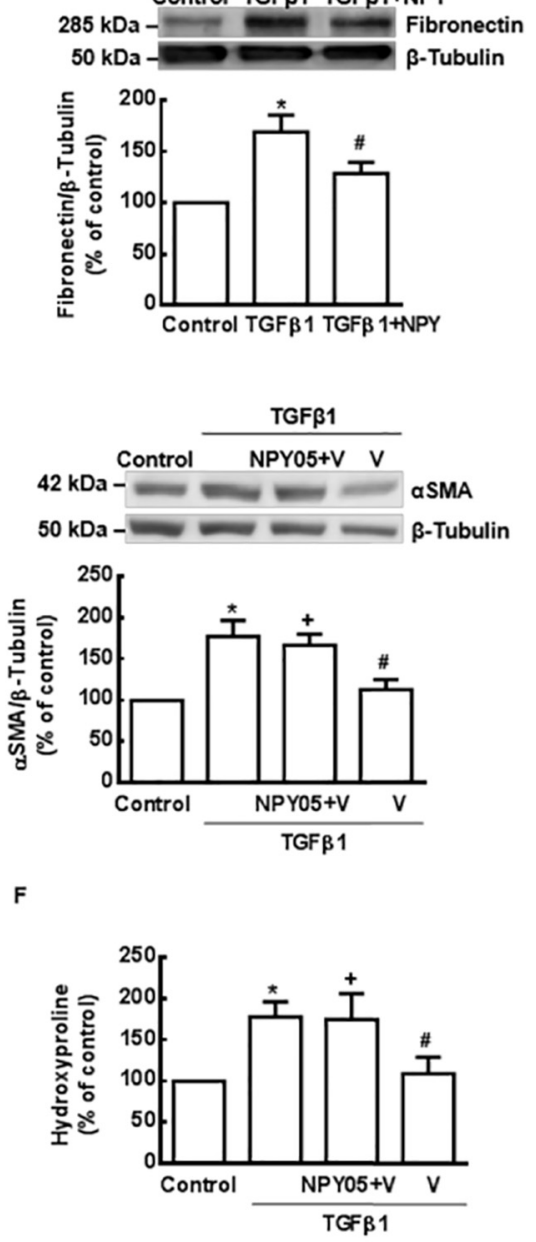

G

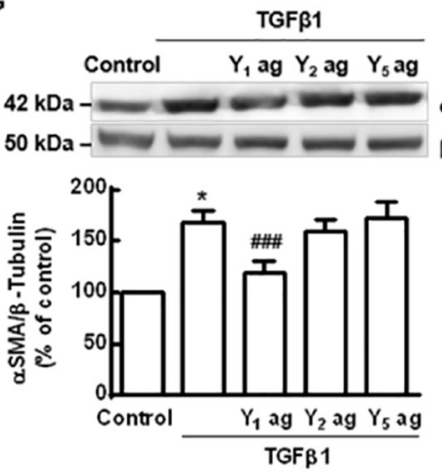

H
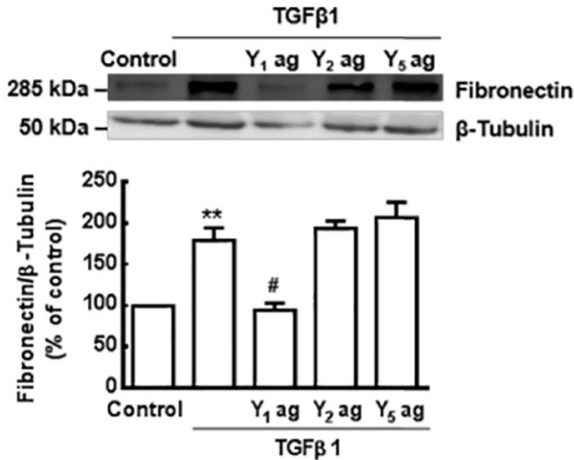

Fig. 4. DPP-IV inhibitor prevents fibrosis through NPY and NPY $Y_{1}$ receptor activation. 3T3-L1 preadipocytes were induced to differentiate and were treated with TGF $\beta 1$ $(2.5 \mathrm{ng} / \mathrm{mL})$ in the absence or presence of (A-C) NPY; (D-F) vildagliptin $(\mathrm{V}, 2 \mathrm{nM})$ with or without NPY neutralizing antibody (NPY05, $6 \mu \mathrm{g} / \mathrm{mL}$ ) for seven days; (G-I) NPY $Y_{1}$ receptor agonist (Leu ${ }^{31} \mathrm{Pro}^{34} \mathrm{NPY}, 100 \mathrm{nM}$ ), NPY $\mathrm{Y}_{2}$ receptor agonist $\left(\mathrm{NPY}_{13-36}, 100 \mathrm{nM}\right)$ or $\mathrm{NPY} \mathrm{Y}_{5}$ receptor agonist $\left(\mathrm{NPY}_{19-23}\left(\mathrm{Gly}^{1}, \mathrm{Ser}^{3}, \mathrm{Gln}^{4}, \mathrm{Thr}^{6}, \mathrm{Ala}^{31}, \mathrm{Aib}^{32}, \mathrm{Gln}^{34}\right)\right.$ PP, $100 \mathrm{nM}$ ). (A, D, G) $\alpha$ SMA or (B, E, H) fibronectin and $\beta$ tubulin (loading control) immunoreactivity by Western blotting. (C, F, I) Hydroxyproline quantification. $\mathrm{n}=4-7$ *p $<0.05 ; * * p<0.01 ; * * * p<0.001$ compared to control. ${ }^{\#} \mathrm{p}<0.05 ;{ }^{\# \#} \mathrm{p}<0.01 ;{ }^{\# \#} \mathrm{p}<0.001$ compared to TGF $31 .+{ }^{+} \mathrm{p}<0.05 ; \quad{ }^{++} \mathrm{p}<0.01$ compared to TGF $31+$ V. One-way ANOVA was used as statistical test.

I

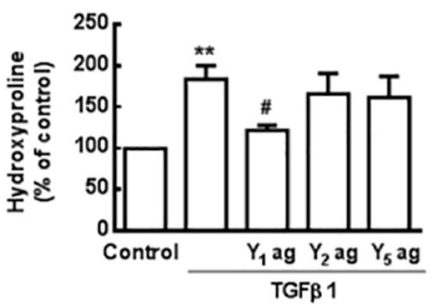


[28]. We observed that when NPY effect is neutralized, the inhibitory effect of vildagliptin on aSMA, fibronectin and total collagen in TGF $\beta 1$ treated cells is partially reverted (Fig. 4D-F). To evaluate which NPY receptor was involved in this antifibrotic effect induced by NPY, preadipocytes were incubated with TGF $\beta 1$ in the presence of NPY $Y_{1}$ receptor agonist (Leu ${ }^{31} \mathrm{Pro}^{34} \mathrm{NPY}, 100 \mathrm{nM}$ ), NPY $\mathrm{Y}_{2}$ receptor agonist $\left(\mathrm{NPY}_{13-36}, 100 \mathrm{nM}\right)$ or NPY $\mathrm{Y}_{5}$ receptor agonist $\left(\mathrm{NPY}_{19-23}\left(\mathrm{Gly}^{1}, \mathrm{Ser}^{3}, \mathrm{Gln}^{4}, \mathrm{Thr}^{6}, \mathrm{Ala}^{31}, \mathrm{Aib}^{32}, \mathrm{Gln}^{34}\right) \mathrm{PP}, 100 \mathrm{nM}\right)$. We observed that NPY $Y_{1}$ receptor agonist decreases $\alpha$ SMA, fibronectin, and total collagen upregulation induced by TGF 31 (Fig. 4G-I). NPY $\mathrm{Y}_{2}$ receptor agonist or the NPY $\mathrm{Y}_{5}$ receptor agonist do not change the levels of $\alpha$ SMA, fibronectin and total collagen (Fig. 4G-I). These results show that NPY prevents ECM deposition by NPY $Y_{1}$ receptor activation and that vildagliptin antifibrotic effect occurs partially through preserving NPY that will activate NPY $Y_{1}$ receptor.

\section{Discussion}

Obesity is associated with an excessive increase of WAT. It has been described an excessive ECM remodeling, that leads to fibrosis formation in adipose tissue in obesity [3]. Adipose tissue fibrosis limits normal expansion of the tissue, leading to metabolic complications in obesity. Vildagliptin is a selective and competitive inhibitor of DPP-IV that is currently being used in the treatment of type 2 diabetes [13]. Moreover, there is evidence that DPP-IV inhibitors have other effects besides glycemic control, such as hypolipidemic effect [29]. Some studies have already described that DPP-IV inhibitors are able to prevent fibrosis formation in the liver, kidney and heart [16-18]. Taking this into account, in this study we investigated the potential effect of DPP-IV inhibitor, vildagliptin, in the prevention of fibrosis in adipose tissue of obese mice, induced by HFD. In this work, HFD induces an increase of body and epididymal adipose tissue weight and adipocyte diameter. HFD-fed mice also showed, as already described [30], an increase of fasting blood glucose, impaired glucose tolerance, an increase in serum cholesterol, triglycerides, insulin and leptin and also an increase of fat accumulation by the liver. Moreover, we observed epididymal adipose tissue fibrosis in HFD mice. Furthermore, we found that vildagliptin, besides improving glycemic control, also improves other serum parameters such as triglycerides, cholesterol and leptin in HFD-fed mice. Vildagliptin also improves lipid accumulated by the liver of HFD mice. The effect of vildagliptin in glycemic control is known to occur through the increase of half-life time of GLP-1 and GIP, which are known to potentiate insulin secretion by pancreatic $\beta$-cells, lowering blood glucose levels, HbA1c, glucagon secretion and liver glucose production [31]. Some of the other effects, namely triglycerides, cholesterol and leptin decrease can be explained by the improvement of glycemic control due to inhibition of DPP-IV [14]. Several studies described that DPP-IV inhibitors improve blood cholesterol and triglycerides, both in humans [32-34] and rodents [14,35].

Moreover, although there were no significant differences in body weight change nor adipose tissue mass, we observed a decrease in fibrosis in WAT of obese mice treated with vildagliptin. These findings represent the first evidence, to our knowledge, that DPP-IV inhibition prevents fibrosis in adipose tissue in a diet-induced obesity rodent model. The antifibrotic role of vildagliptin in non-adipose tissues has already been described by others $[36,37]$. The antifibrotic role will putatively decrease the stiffness of the tissue and thereby improve adipocyte ability to store lipids, and can be a cause for the amelioration of other parameters that we observed in this study, such as decrease in serum triglycerides and cholesterol and also ectopic lipid accumulation in the liver. All of these parameters are hallmarks of metabolic syndrome, so amelioration of these parameters suggests that vildagliptin could have an important role in obesity complications and thereby contribute to health improvement. In fact, it was already observed that collagen VI deficient $o b / o b$ and HFD-fed mice also have less adipose tissue fibrosis [7]. These mice have more fat mass with improved insulin sensitivity, suggesting that adipose tissue fibrosis may be an important determinant of insulin sensitivity [7]. The inhibition of fibrosis in WAT decreases its rigidity and this might facilitate weight loss. In obese patients, subcutaneous adipose tissue revealed persistence of fibrosis two years after bariatric surgery [38] and adipose tissue fibrosis is even found negatively associated with weight loss induced by bariatric surgery [6]. All of these studies are important reinforcements for the role of fibrosis on adipose tissue homeostasis and its consequences during obesity process.

Some studies report that antifibrosis leads to an increase in fat mass and in fat cells [7]. However, we observed no alteration in adipocyte diameter nor in adipose tissue weight in vildagliptin-treated animals with less fibrosis. Although DPP-IV inhibitors are considered to be weight neutral in humans, several studies showed that DPP-IV inhibitors induced weight loss $[39,40]$. DPP-IV inhibitors have an antifibrotic effect, but it is also important in adipocyte physiology. In vitro studies showed that vildagliptin could prevent adipocyte differentiation in 3T3-L1 preadipocytes [26]. Moreover, the authors also described that vildagliptin inhibits lipid accumulation, thereby reducing fat cell size [26]. It was described that DPP-IV inhibition prevents hypertrophy of fat cells in epididymal white adipose tissue in HFD-fed mice [40]. Mice lacking the DPP-IV gene are resistant to the development of obesity, adiposity and adipocyte hypertrophy induced by HFD, associated with reduced energy intake and increased energy expenditure [41]. Moreover, DPP-IV deficiency leads to up-regulation of PPAR $\alpha$ and downregulation of SREBP-1 expression in the liver, attenuating lipogenesis and increasing fat oxidation [41]. These results suggest that reduced hepatic lipid accumulation in DPP-IV $-/-$ mice is associated with attenuated lipogenesis and increased fat oxidation. Therefore, the fact that vildagliptin does not alter adipose tissue weight and adipocyte diameter might occur because of other effects induced in adipocytes such as proliferation, differentiation, lipid accumulation and fat oxidation in adipocytes.

Regarding the mechanisms underlying the antifibrotic effect of vildagliptin in adipose tissue fibrosis, we could hypothesize that it occurs as a consequence of increased GLP-1 levels and consequently improved insulin response and glycemic control [13]. However, several studies showed that DPP-IV inhibitors are able to prevent fibrosis independently of glycemia and GLP-1 in the liver [36], in the heart [42] and in the kidney [43]. Moreover, fibrosis prevention could also be explained by anti-inflammatory effects of DPP-IV inhibitors and GLP-1 that were both described to prevent inflammation in WAT $[40,44]$. It is widely recognized that obesity is an inflammatory state and fibrosis is perceived by many as a process secondary to tissue inflammation [45]. But in fact little is known about this triad and the causal relationships between adipose tissue fibrosis and inflammation remain to be defined.

To better understand the putative mechanism underlying fibrosis prevention by vildagliptin in adipose tissue, we used an in vitro model of 3T3-L1 preadipocytes and showed that both vildagliptin and a genetic approach of DPP-IV silencing suppress TGF $\beta 1$-mediated stimulatory effects on the profibrotic markers: $\alpha$ SMA, fibronectin, collagen VI and total collagen deposition. DPP-IV inhibitors were shown to have antifibrotic effects also in vitro in other cell types $[17,46]$. Inhibition of DPPIV was performed through pharmacological and genetic approaches. Genetic silencing of DPP-IV resulted in similar results to those obtained with vildagliptin. These results show that the antifibrotic effects that we obtained with vildagliptin occur specifically through inhibition of catalytic function of DPP-IV, and not through non-specific, off-target effects. DPP-IV has several other substrates, such as NPY [47]. DPP-IV removes $\mathrm{N}$-terminal dipeptide changing the receptor sub-type specificity from $\mathrm{Y}_{1}\left(\mathrm{NPY}_{1-36}\right)$ to $\mathrm{Y}_{2} / \mathrm{Y}_{5}\left(\mathrm{NPY}_{3-36}\right)$ [48]. Moreover, NPY has an important role in the development of adipose tissue and increases proliferation and differentiation of adipocytes through NPY $\mathrm{Y}_{2}$ and $\mathrm{Y}_{5}$ receptors [19]. It has been demonstrated that DPP-IV inhibition facilitates the anti-lipolytic effects of NPY through $\mathrm{Y}_{1}$ receptor [8]. Taking into account the NPY relevance in adipose tissue function, we 
hypothesized that NPY might be a possible DPP-IV substrate responsible for the antifibrotic role of vildagliptin. In this study, we showed that the vildagliptin effect occurs partially through its action in NPY that in turn activates NPY $\mathrm{Y}_{1}$ receptor. These results are in agreement with the "expandability theory". If vildagliptin acts through decrease NPY cleavage to inhibit fibrosis, it might allow adipocytes to expand and accumulate lipids, thereby inhibiting lipolysis. Others previously showed that NPY decreases fibrosis in a swine model of chronic myocardial ischemia and hypercholesterolemia [20]. Moreover, NPY overexpression reduces the development of cardiac fibrosis in other rat model [21]. Another study observed that mice lacking NPY $Y_{1}$ receptor also have a larger volume fraction of myocardial fibrosis [22], corroborating our results.

In summary, this study establishes that a DPP-IV inhibitor significantly protects against adipose tissue fibrosis formation.

\section{Transparency document}

The Transparency document associated with this article can be found, in online version.

\section{Acknowledgements}

We would like to acknowledge Eric Grouzmann for providing the antibody NPY05. This work was supported by FEDER funds through the Operational Programme Factors Competitiveness - COMPETE 2020, by National Funds through FCT-Foundation for Science and Technology under the Strategic Project (UID/NEU/04539/2013, PTDC/SAU-FCF/ 102415/2008, SFRH/BD/51674/2011， SFRH/BPD/31547/2006, SFRH/BPD/78424/2011), by QREN-Projeto Mais Centro-“Aging, Stress and Chronic Diseases: from Mechanisms to Therapeutics", by a Project Grant for Obesity investigation provided by the Portuguese Society of Endocrinology and Metabolism (SPEDM) and Abbot, and by L'Oreal Women for Science Program (FCT/UNESCO-Portugal).

\section{References}

[1] A. Vidal-Puig, Adipose tissue expandability, lipotoxicity and the metabolic syndrome, Endocrinol. Nutr. 60 (Suppl. 1) (2013) 39-43.

[2] E.C. Mariman, P. Wang, Adipocyte extracellular matrix composition, dynamics and role in obesity, Cell. Mol. Life Sci. 67 (2010) 1277-1292.

[3] M. Spencer, A. Yao-Borengasser, R. Unal, N. Rasouli, C.M. Gurley, B. Zhu, C.A. Peterson, P.A. Kern, Adipose tissue macrophages in insulin-resistant subjects are associated with collagen VI and fibrosis and demonstrate alternative activation, Am. J. Physiol. Endocrinol. Metab. 299 (2010) E1016-1027.

[4] A.M. Gressner, R. Weiskirchen, Modern pathogenetic concepts of liver fibrosis suggest stellate cells and TGF-beta as major players and therapeutic targets, J. Cell. Mol. Med. 10 (2006) 76-99.

[5] J.F. Woessner Jr., The determination of hydroxyproline in tissue and protein samples containing small proportions of this imino acid, Arch. Biochem. Biophys. 93 (1961) 440-447.

[6] A. Divoux, J. Tordjman, D. Lacasa, N. Veyrie, D. Hugol, A. Aissat, A. Basdevant, M. Guerre-Millo, C. Poitou, J.D. Zucker, P. Bedossa, K. Clement, Fibrosis in human adipose tissue: composition, distribution, and link with lipid metabolism and fat mass loss, Diabetes 59 (2010) 2817-2825.

[7] T. Khan, E.S. Muise, P. Iyengar, Z.V. Wang, M. Chandalia, N. Abate, B.B. Zhang, P. Bonaldo, S. Chua, P.E. Scherer, Metabolic dysregulation and adipose tissue fibrosis: role of collagen VI, Mol. Cell. Biol. 29 (2009) 1575-1591.

[8] K. Kos, A.R. Baker, M. Jernas, A.L. Harte, J.C. Clapham, J.P. O'Hare, L. Carlsson, S. Kumar, P.G. McTernan, DPP-IV inhibition enhances the antilipolytic action of NPY in human adipose tissue, Diabetes Obes. Metab. 11 (2009) 285-292.

[9] L. Bouchard, G. Faucher, A. Tchernof, Y. Deshaies, S. Lebel, F.S. Hould, P. Marceau, M.C. Vohl, Comprehensive genetic analysis of the dipeptidyl peptidase-4 gene and cardiovascular disease risk factors in obese individuals, Acta Diabetol. 46 (2009) $13-21$.

[10] A.M. Lambeir, C. Durinx, S. Scharpe, I. De Meester, Dipeptidyl-peptidase IV from bench to bedside: an update on structural properties, functions, and clinical aspects of the enzyme DPP IV, Crit. Rev. Clin. Lab. Sci. 40 (2003) 209-294.

[11] E.E. Mulvihill, D.J. Drucker, Pharmacology, physiology, and mechanisms of action of dipeptidyl peptidase-4 inhibitors, Endocr. Rev. 35 (2014) 992-1019.

[12] R. Mentlein, Dipeptidyl-peptidase IV (CD26)-role in the inactivation of regulatory peptides, Regul. Pept. 85 (1999) 9-24.

[13] D.J. Drucker, M.A. Nauck, The incretin system: glucagon-like peptide-1 receptor agonists and dipeptidyl peptidase-4 inhibitors in type 2 diabetes, Lancet 368 (2006)
1696-1705.

[14] L. Ferreira, E. Teixeira-de-Lemos, F. Pinto, B. Parada, C. Mega, H. Vala, R. Pinto, P. Garrido, J. Sereno, R. Fernandes, P. Santos, I. Velada, A. Melo, S. Nunes, F. Teixeira, F. Reis, Effects of sitagliptin treatment on dysmetabolism, inflammation, and oxidative stress in an animal model of type 2 diabetes (ZDF rat), Mediat. Inflamm. 2010 (2010) 592760.

[15] Z. Shah, T. Kampfrath, J.A. Deiuliis, J. Zhong, C. Pineda, Z. Ying, X. Xu, B. Lu, S. Moffatt-Bruce, R. Durairaj, Q. Sun, G. Mihai, A. Maiseyeu, S. Rajagopalan, Longterm dipeptidyl-peptidase 4 inhibition reduces atherosclerosis and inflammation via effects on monocyte recruitment and chemotaxis, Circulation 124 (2011) 2338-2349.

[16] B. Bostick, J. Habibi, L. Ma, A. Aroor, N. Rehmer, M.R. Hayden, J.R. Sowers, Dipeptidyl peptidase inhibition prevents diastolic dysfunction and reduces myocardial fibrosis in a mouse model of western diet induced obesity, Metab. Clin. Exp. 63 (2014) 1000-1011.

[17] K. Kaji, H. Yoshiji, Y. Ikenaka, R. Noguchi, Y. Aihara, A. Douhara, K. Moriya, H. Kawaratani, Y. Shirai, J. Yoshii, K. Yanase, M. Kitade, T. Namisaki, H. Fukui, Dipeptidyl peptidase-4 inhibitor attenuates hepatic fibrosis via suppression of ac tivated hepatic stellate cell in rats, J. Gastroenterol. 49 (2014) 481-491.

[18] K. Kanasaki, S. Shi, M. Kanasaki, J. He, T. Nagai, Y. Nakamura, Y. Ishigaki, M. Kitada, S.P. Srivastava, D. Koya, Linagliptin-mediated DPP-4 inhibition ameliorates kidney fibrosis in streptozotocin-induced diabetic mice by inhibiting endothelial-to-mesenchymal transition in a therapeutic regimen, Diabetes 63 (2014) 2120-2131.

[19] J. Rosmaninho-Salgado, V. Cortez, M. Estrada, M.M. Santana, A. Goncalves, A.P. Marques, C. Cavadas, Intracellular mechanisms coupled to NPY Y2 and Y5 receptor activation and lipid accumulation in murine adipocytes, Neuropeptides 46 (2012) 359-366.

[20] R. Matyal, S. Sakamuri, A. Wang, E. Mahmood, M.P. Robich, K. Khabbaz, P.E. Hess, F.W. Sellke, F. Mahmood, Local infiltration of neuropeptide Y as a potential therapeutic agent against apoptosis and fibrosis in a swine model of hypercholesterolemia and chronic myocardial ischemia, Eur. J. Pharmacol. 718 (2013) 261-270.

[21] M. Michalkiewicz, G. Zhao, Z. Jia, T. Michalkiewicz, M.J. Racadio, Central neuropeptide Y signaling ameliorates N(omega)-nitro-L-arginine methyl ester hypertension in the rat through a Y1 receptor mechanism, Hypertension 45 (2005) 780-785.

[22] T. Costoli, A. Sgoifo, D. Stilli, G. Flugge, W. Adriani, G. Laviola, E. Fuchs, T. Pedrazzini, E. Musso, Behavioural, neural and cardiovascular adaptations in mice lacking the NPY Y1 receptor, Neurosci. Biobehav. Rev. 29 (2005) 113-123.

[23] L.C. Junqueira, G. Bignolas, R.R. Brentani, Picrosirius staining plus polarization microscopy, a specific method for collagen detection in tissue sections, Histochem. J. 11 (1979) 447-455.

[24] L.P. de Almeida, D. Zala, P. Aebischer, N. Deglon, Neuroprotective effect of a CNTF expressing lentiviral vector in the quinolinic acid rat model of Huntington's disease, Neurobiol. Dis. 8 (2001) 433-446.

[25] A.P. Marques, J. Rosmaninho-Salgado, M. Estrada, V. Cortez, R.J. Nobre, C. Cavadas, Hypoxia mimetic induces lipid accumulation through mitochondrial dysfunction and stimulates autophagy in murine preadipocyte cell line, Biochim. Biophys. Acta 1861 (3) (2016) 673-682.

[26] J. Rosmaninho-Salgado, A.P. Marques, M. Estrada, M. Santana, V. Cortez, E. Grouzmann, C. Cavadas, Dipeptidyl-peptidase-IV by cleaving neuropeptide Y induces lipid accumulation and PPAR-gamma expression, Peptides 37 (2012) 49-54.

[27] Q. Xu, J.T. Norman, S. Shrivastav, J. Lucio-Cazana, J.B. Kopp, In vitro models of TGF-beta-induced fibrosis suitable for high-throughput screening of antifibrotic agents, Am. J. Physiol. Ren. Physiol. 293 (2007) F631-640.

[28] E. Grouzmann, F. Cressier, P. Walker, K. Hofbauer, B. Waeber, H.R. Brunner, Interactions between NPY and its receptor: assessment using ant-NPY antibodies, Regul. Pept. 54 (1994) 439-444.

[29] M. Rizzo, A.A. Rizvi, G.A. Spinas, G.B. Rini, K. Berneis, Glucose lowering and antiatherogenic effects of incretin-based therapies: GLP-1 analogues and DPP-4-inhibitors, Expert Opin. Investig. Drugs 18 (2009) 1495-1503.

[30] S. Collins, T.L. Martin, R.S. Surwit, J. Robidoux, Genetic vulnerability to diet-induced obesity in the C57BL/6J mouse: physiological and molecular characteristics, Physiol. Behav. 81 (2004) 243-248.

[31] D. Elahi, M. McAloon-Dyke, N.K. Fukagawa, G.S. Meneilly, A.L. Sclater, K.L. Minaker, J.F. Habener, D.K. Andersen, The insulinotropic actions of glucosedependent insulinotropic polypeptide (GIP) and glucagon-like peptide-1 (7-37) in normal and diabetic subjects, Regul. Pept. 51 (1994) 63-74.

[32] N. Matikainen, S. Manttari, A. Schweizer, A. Ulvestad, D. Mills, B.E. Dunning, J.E. Foley, M.R. Taskinen, Vildagliptin therapy reduces postprandial intestinal triglyceride-rich lipoprotein particles in patients with type 2 diabetes, Diabetologia 49 (2006) 2049-2057.

[33] A.J. Tremblay, B. Lamarche, C.F. Deacon, S.J. Weisnagel, P. Couture, Effect of sitagliptin therapy on postprandial lipoprotein levels in patients with type 2 diabetes, Diabetes Obes. Metab. 13 (2011) 366-373.

[34] B. Eliasson, D. Moller-Goede, K. Eeg-Olofsson, C. Wilson, J. Cederholm, P. Fleck, M. Diamant, M.R. Taskinen, U. Smith, Lowering of postprandial lipids in individuals with type 2 diabetes treated with alogliptin and/or pioglitazone: a randomised double-blind placebo-controlled study, Diabetologia 55 (2012) 915-925.

[35] V.A. Gault, R. Lennox, P.R. Flatt, Sitagliptin, a dipeptidyl peptidase-4 inhibitor, improves recognition memory, oxidative stress and hippocampal neurogenesis and upregulates key genes involved in cognitive decline, Diabetes Obes. Metab. 17 (2015) 403-413.

[36] T. Klein, M. Fujii, J. Sandel, Y. Shibazaki, K. Wakamatsu, M. Mark, H. Yoneyama, Linagliptin alleviates hepatic steatosis and inflammation in a mouse model of nonalcoholic steatohepatitis, Med. Mol. Morphol. 47 (2014) 137-149. 
[37] H. Hirakawa, H. Zempo, M. Ogawa, R. Watanabe, J. Suzuki, H. Akazawa, I. Komuro, M. Isobe, A DPP-4 inhibitor suppresses fibrosis and inflammation on experimental autoimmune myocarditis in mice, PLoS One 10 (2015) e0119360.

[38] R. Cancello, A. Zulian, D. Gentilini, M. Mencarelli, A. Della Barba, M. Maffei, P. Vitti, C. Invitti, A. Liuzzi, A.M. Di Blasio, Permanence of molecular features of obesity in subcutaneous adipose tissue of ex-obese subjects, Int. J. Obes. 37 (2013) 867-873.

[39] B.J. Lamont, D.J. Drucker, Differential antidiabetic efficacy of incretin agonists versus DPP-4 inhibition in high fat fed mice, Diabetes 57 (2008) 190-198.

[40] A.D. Dobrian, Q. Ma, J.W. Lindsay, K.A. Leone, K. Ma, J. Coben, E.V. Galkina, J.L. Nadler, Dipeptidyl peptidase IV inhibitor sitagliptin reduces local inflammation in adipose tissue and in pancreatic islets of obese mice, Am. J. Physiol. Endocrinol. Metab. 300 (2011) E410-421.

[41] S.L. Conarello, Z. Li, J. Ronan, R.S. Roy, L. Zhu, G. Jiang, F. Liu, J. Woods, E. Zycband, D.E. Moller, N.A. Thornberry, B.B. Zhang, Mice lacking dipeptidyl peptidase IV are protected against obesity and insulin resistance, Proc. Natl. Acad. Sci. U. S. A. 100 (2003) 6825-6830.

[42] K.A. Connelly, Y. Zhang, A. Advani, S.L. Advani, K. Thai, D.A. Yuen, R.E. Gilbert, DPP-4 inhibition attenuates cardiac dysfunction and adverse remodeling following myocardial infarction in rats with experimental diabetes, Cardiovasc. Ther. 31 (2013) 259-267.
[43] H.S. Min, J.E. Kim, M.H. Lee, H.K. Song, Y.S. Kang, M.J. Lee, J.E. Lee, H.W. Kim, J.J. Cha, Y.Y. Chung, Y.Y. Hyun, J.Y. Han, D.R. Cha, Dipeptidyl peptidase IV inhibitor protects against renal interstitial fibrosis in a mouse model of ureteral obstruction, Lab. Investig. 94 (2014) 598-607.

[44] Y.S. Lee, M.S. Park, J.S. Choung, S.S. Kim, H.H. Oh, C.S. Choi, S.Y. Ha, Y. Kang, Y. Kim, H.S. Jun, Glucagon-like peptide-1 inhibits adipose tissue macrophage infiltration and inflammation in an obese mouse model of diabetes, Diabetologia 55 (2012) 2456-2468.

[45] C. Henegar, J. Tordjman, V. Achard, D. Lacasa, I. Cremer, M. Guerre-Millo, C. Poitou, A. Basdevant, V. Stich, N. Viguerie, D. Langin, P. Bedossa, J.D. Zucker, K. Clement, Adipose tissue transcriptomic signature highlights the pathological relevance of extracellular matrix in human obesity, Genome Biol. 9 (2008) R14.

[46] A. Thielitz, R.W. Vetter, B. Schultze, S. Wrenger, L. Simeoni, S. Ansorge, K. Neubert, J. Faust, P. Lindenlaub, H.P. Gollnick, D. Reinhold, Inhibitors of dipeptidyl peptidase IV-like activity mediate antifibrotic effects in normal and keloid-derived skin fibroblasts, J. Invest. Dermatol. 128 (2008) 855-866.

[47] R. Mentlein, P. Dahms, D. Grandt, R. Kruger, Proteolytic processing of neuropeptide Y and peptide YY by dipeptidyl peptidase IV, Regul. Pept. 49 (1993) 133-144.

[48] L. Grundemar, J.L. Krstenansky, R. Hakanson, Activation of neuropeptide Y1 and neuropeptide Y2 receptors by substituted and truncated neuropeptide Y analogs: identification of signal epitopes, Eur. J. Pharmacol. 232 (1993) 271-278. 